https://doi.org/10.15407/frg2020.03.258

UDK 632.938:633.11+632.4

\title{
UNIQUE SOURCES OF RESISTANCE TO FUSARUIM HEAD BLIGHT FOR DURUM WHEAT
}

\author{
G. FEDAK ${ }^{1}$, D. WOLFE ${ }^{1}$, D. CHI ${ }^{1}$, S. CLOUTIER ${ }^{1}$, A. XUE ${ }^{1}$, L. ZHANG ${ }^{2}$ \\ ${ }^{1}$ Ottawa Research and Development Centre of Agriculture and Agri-Food of Canada \\ Ottawa, Ontario, Canada \\ ${ }^{2}$ Triticale Research Institute, Sichuan Agriculture University \\ Chengdu City, Sichuan province, China
}

Fifteen accessions of Triticum dicoccum tetraploid wild relatives of durum wheat were screened for Type II Fusarium head blight (FHB) resistance. Single florets on spike at $50 \%$ anthesis were inoculated with spores of Fusarium graminearum and symptoms were scored at 21 days after inoculation. The range of infected florests varied from $6 \%$ to $100 \%$ compared to Langdon atypical sensitive durum wheat cultivar at $75 \%$. Six selected the most resistant accessions were used in the trial, which range of infection varied from $6 \%$ to $8 \%$.

Key words: Triticum dicoccum, Fusarium graminearum, resistance, durum wheat, symptoms.

The level of variability for FHB resistance in the primary and secondary gene pools of tetraploid wheat is very low compared to the situation in hexaploid wheat. The search for variability has been extensive, with meager results.

In a search of the literature, reporting 6 studies covering over 1300 accessions, mainly $T$. dicoccoides strains from gene banks, negligible resistance was found [1]. Resistance has also been reported in T. dicoccum [2-4] and in $T$. dicoccoides [5]. In our own previous studies, a strain of $T$. carthlicum, named Blackbrid carried a QTL on chromosome 6BS [6]. Resistance was also found in a partial amphiploid derived from hybrids between durum wheat and Thinopirum elongatum [7].

The need for variability for FHB resistance in durum wheat has became more urgent following an FHB epidemic in Canada in 2016.

\section{Materials and Methods}

A total of fifteen $T$. dicoccum accessions which were obtained from the USDA genebank at Aberdeen Idaho were inoculated by point inoculation following standard procedures. This involved the injection of $10 \mu \mathrm{l}$ of inoculum at a concentration of 50,000 spores per $\mathrm{ml}$ into a central floret at $50 \%$ anthesis following a 48 hour misting exposure. The percent of

Citation: Fedak G., Wolfe D., Chi D., Cloutier S., Xue A., Zhang L. Unique sources of resistance to Fusaruim head blight for durum wheat. FizioL. rast. genet., 2020, 52, No. 3, pp. 258-261. https://doi.org/10.15407/frg2020.03.258 
TABLE 1. Average percent of infected florets of selected T. dicoccum strains at 21 day

\begin{tabular}{|c|c|c|}
\hline Line ID & Trial 1 FHB infection (\%) & Trial 2 FHB infection (\%) \\
\hline $\mathrm{C} 2$ & 6 & 8 \\
\hline $\mathrm{C} 3$ & 20 & - \\
\hline $\mathrm{C} 4$ & 6 & 6 \\
\hline $\mathrm{C} 5$ & 39 & - \\
\hline C6 & 7 & 7 \\
\hline $\mathrm{C} 7$ & 6 & 6 \\
\hline $\mathrm{C} 8$ & 30 & - \\
\hline C9 & 13 & - \\
\hline $\mathrm{C} 12$ & 12 & 7 \\
\hline $\mathrm{C} 13$ & 9 & 6 \\
\hline $\mathrm{C} 14$ & 20 & - \\
\hline $\mathrm{C} 15$ & 6 & - \\
\hline $\mathrm{C} 16$ & 15 & - \\
\hline $\mathrm{C} 17$ & 100 & - \\
\hline $\mathrm{C} 18$ & 95 & - \\
\hline Langdon & 73 & 75 \\
\hline
\end{tabular}

infected florets was estimated at 21 days after inoculation. A minimum of five spikes were inoculated for each accession at each trial.

\section{Results and discussion}

The floret infection percentages of the fifteen dicoccum accessions tested ranged from approximately $5 \%$ to $100 \%$ compared to the Langdon check at $73 \%$ infection (Table 1). The test was repeated on six of the best lines from trial 1 (trial 2). Similar results were obtained.

This should be valuable germplasm for durum wheat improvement. Some of the accessions are tall and late as expected from wild species. Such negative traits should be easily removed in segregating populations. Positive attributes of other accessions of $T$. dicoccum include a large seed size and large spikes.

The $T$. dicoccum accessions studied have varied and diverse backgrounds. Some date back to collection made by N.I. Vavilov and deposited in gene banks in the 1930s (Table 2).

The results shown in Table 1 are frequencies of infected florets observed following point inoculation in Type II resistance or resistance to spread of the infection. Those same accessions need to be grown in full nurseries and evaluated for resistance to initial infection (Type I resistance). This was the situation we encountered with Blackbird. In an initial study we detected a QTL on chromosomes 6B that provided Type II resistance [8]. In a subsequent study [9] Type I resistance was detected.

Langdon is a typical modern durum wheat cultivar. Its FHB rating is typical of modern durum wheat cultivars. The resistance observed in the 
G. FEDAK, D. WOLFE, D. CHI, S. CLOUTIER, A. XUE, L. ZHANG

\begin{tabular}{l|c|c}
\hline \multicolumn{2}{c}{ TABLE 2. Geographic origin of $T$. dicoccum lines } \\
\hline \multicolumn{1}{c}{ C\# } & PI\# & Geographical Origin \\
\hline C2 & PI 94614 & Kharkiv, 1931 (V*) \\
C4 & PI 94650 & Czechoslovakia, 1931 (V) \\
C6 & PI 94666 & Dagestan, 1930 \\
C7 & PI 94675 & Georgia, 1930 (V) \\
C12 & PI 352335 & Minnesota, 1919 (USA) \\
C13 & PI 355465 & Gembloux, Belgium \\
\hline
\end{tabular}

*Original collection by N.I. Vavilov .

present experiment among the $T$. dicoccum accessions should be useful geneplasm to use to improve FHB ratings of durum cultivar.

Recently it has been found that numerous alien introductions carry resistance to a multitude of diseases. Table 1 lists the FHB ratings of the $T$. dicoccum accessions evaluated. In future these accessions will be evaluated for resistance to other diseases such as stem rust. The T. carthlicum strain Blackbird was also found to carry resistance to leaf rust and loose smut in addition to FHB.

\section{REFERENCES}

1. Oliver, R.E., Stack, R.W., Miller, J.D. \&. Cai, X. (2008). Reaction of Wild Emmer Wheat Accessions to Fusarium Head Blight. Crop Science Abstract - Plant Genetic Resources, 47, No. 2, pp. 893-897. https://doi.org/10.2135/cropsci2006.08.0531

2. Buerstmayr, M., Haba, K., Heckmann, I., Steiner, B., Nelson, J.C. \& Buerstmayr, H. (2012). Mapping of QTL for FHB resistance and morphological and developmental traits in three backcross populations derived from T. dicoccum x T. durum. Theor. Appl. Genet., 125, pp. 1751-1765.

3. Ruan, Y., Comeau, A., Langevin, F., Hucl, P., Clarke, J. \& Brule-Babel, A. (2012). Identification of Novel QTL for resistance to Fusarium blight is a tetraploid wheat population. Genome, 551, pp. 553-564.

4. Zhang, Q., Axtman, J.E., Faris, J.D., Chao, S., Zhong, Z. \& Friesen, T.L. (2014). Identification and molecular mapping of QTL for FHB resistance inemmer and durum wheat using a simple nucleotide polymorphism-based linkage map. Mol. Breed., 34, pp. 1677-1687.

5. Buerstmayr, M., Alimari, A., Steiner, B. \& Buerstmayr, H. (2013). Genetic mapping of QTL for resistance to Fusarium head blight spread (Type 2) in a T. dicoccoides $\mathrm{X} T$. durum backcross-derived population. Theor. Appl. Genet., 126, pp. 2825-2834.

6. Somers, D.J., Fedak, G. \& Savard, M. (2003). Molecular mapping of novel genes controlling Fusarium head blight resistance and deoxynivalenol accumulation in spring wheat. Genome, 46, pp. 555-564.

7. Han, F.P., Fedak, G., Ouellet, T., Dan, H. \& Somers, D.J. (2005). Mapping of genes expressed in Fusarium graminearum-infected heads of wheat cultivar 'Frontana'. Genome, 48, pp. 88-96.

8. Singh, AK., Knox, R., Clarke, F.R,. Clarke, J.M., Somers, D.J., Fedak, G., Singh, A. \& DePauw, R. (2008). Fusarium head blight QtL mapping in durum wheat and Triticum carthlicum sources of resistance. Proceedings of the 11th International Wheat Genetics Symposium, Brisbane Australia.

9. Chen, S., Huang Z., Dai, Y., Qin, S., Gao, Y., Zhang, L., Gao, Y. \& Chen, J. (2013) The development of 7E chromosome-specific molecular markers for Thinopyrum elongatum based on SLAF-seq technology. PloS One, 8, pp. e65122. 
10. Dvorak, J. \& Knott, D.R. (1974). Disomic and ditelosomic additions of diploid Agropyron elongatum chromosomes to Triticum aestivum. Can. J. Genet. Cytol., 16, pp. 399-417.

11. Fedak, G., Cao, W., Chi, D., Sommers, D., Miller, S., Ouellet, T., Xue, A., Gilbert, J., Savard, M. \& Voldeng, H. (2011). New sources of resistance to Fusarium head blight and their mode of action. In: S. Canty, A. Clark, A. Anderson, Scully, D. Eller and D. Van Sanford (Eds). Proceedings of the 2011, National Fusarium head Blight Forum (pp. 19-22). East Lansing, MI/ Lexington KY: U.S. Wheat and Barley Scab initiative.

12. Gou, L., Hattori, J., Fedak, G., Balcerzak, M., Sharpe, A., Visendi, P., Edwards, D., Think, N., Wei, Y.-M., Chen, G.-Y. \& Ouellet, T. (2016). Development and validation of Thinopyrum elongatum expressed molecular markers specific for the long arm of chromosome 7E. Crop Sci., 56, pp. 354-364.

13. Hu, L.-J., Liu, C., Zeng, Z.-X., Li, G.-R., Song, X.-J. \& Yang, Z.-J. (2012). Genomic rearrangement between wheat and Thinopyrum elongatum revealed by mapped functional molecular markers. Genes. Genom., 34, pp. 67-75. https://doi.org/10.1007/ s13258-011-0153-7

14. Somers, D., Isaac, P. \& Edwards, K. (2004). A high-density microsatellite consensus map for bread wheat (T. aestivum L.). Theor. Appl. Genet., 109, pp. 1105-1114.

15. Zeng, J., Cao, W., Fedak, G., Sun, S., McCallum, B.D., Fetch, T.G. \& Xue, A.G. (2013). Molecular cytogenetic characterization of two novel durum - Thinopysum intermedium partial amphiploid with resistance to leaf rust, stem rust, and Fusarium head blight. Hereditas, 150, pp. 10-16.

Received 20.01.2020

\title{
УНІКАЛЬНІ ДЖЕРЕЛА СТІЙКОСТІ ДО ФУЗАРІОЗУ КОЛОСА ДЛЯ ТВЕРДОЇ ПШЕНИЦі
}

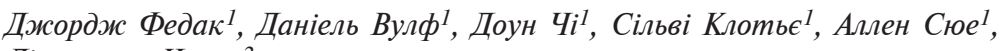 \\ Ліанцюань Чжан ${ }^{2}$ \\ ${ }^{1}$ Оттавський центр досліджень і розробок сільського господарства і \\ агропродовольства Канади, Оттава, Онтаріо, Канада \\ ${ }^{2}$ Інститут досліджень тритикале, Сичуанський аграрний університет, місто Ченду, \\ провінція Сичуань, Китай
}

Проведено скринінг п’ятнадцяти зразків Triticum dicoccum, тетраплоїдних диких родичів твердої пшениці на стійкість до фузаріозу колоса II типу (FHB). Поодинокі квіточки на колосі при 50 \%-му цвітінні інокулювали спорами Fusarium graminearum і оцінювали симптоми через 21 день після інокуляції. Діапазон заражених квіток варіював від 6 до $100 \%$ порівняно з нетипово чутливим сортом твердої пшениці Langdon (75 \%). У випробуванні використовували виділені шість найстійкіших зразків, спектр зараження яких варіював від 6 до $8 \%$.

Ключові слова: Triticum dicoccum, Fusarium graminearum, резистентність, тверда пшениця. 